\title{
BIOLOGICAL CHARACTERISTICS OF CELL LINE GL-V3 DERIVED FROM THE KIDNEY OF A VERVET MONKEY (CERCOPITHECUS AETHIOPS)
}

\author{
George J. Christofinis* \\ Virus Research Unit, Glaxo Laboratories Ltd, \\ Greenford, Middlesex \\ Plates XXI AND XXII
}

PRIMARY monkey kidney tissue and cell cultures have been widely used in virus work because of the sensitivity of these cells to a great number of human viruses.

However, primary monkey kidney cultures may be contaminated with viruses indigenous in the monkey. Wood and Shimada (1954), Rustigian, Johnson and Reihart (1955), Hull, Minner and Smith (1956), Hull and Minner (1957), Hull, Minner and Mascoli (1958), Keeble, Christofinis and Wood (1958) and Sweet and Hilleman (1960) reported the isolation of simian viruses from the tissue of the monkeys. In addition, Gordon Smith et al. (1967) isolated an infective agent that caused acute illness and death in German laboratory workers who had been working with tissues obtained from vervet monkeys. Because of these findings, there has been a growing awareness of the need for alternative cell systems to be used in virus research and during the last few years "cell lines" and "cell strains" have been increasingly used.

This paper reports the establishment of a cell line, GL-V3, derived from normal vervet monkey kidney and describes some of its biological characteristics (GL = Glaxo Laboratories Ltd; V3 = vervet no. 3). It was desirable to use vervet monkey kidney tissue to initiate a continuous cell line as these cells show a cytopathic effect when infected with the simian virus SV40. Rhesus and cynomolgus monkey kidney tissue, although often contaminated with this virus, does not show any cytopathic effect.

\section{MATERIALS AND METHODS}

Cell cultures. Attempts were made to establish cell lines from kidney tissue of 12 African green vervet monkeys (Cercopithecus aethiops) in 1962. The cultures were named consecutively GL-V1-GL-V12. The kidneys were removed aseptically and trypsinised by the method of Bishop, Smith and Beale (1960). Cells were cultured at $37^{\circ} \mathrm{C}$ in Roux bottles and Carrel flasks and were subcultured when they became confluent. The cells were removed from the glass with 0.25 per cent. trypsin (Difco) or, when the cultures became established, with a mixture of 0.5 per cent. trypsin and 0.04 per cent. Versene (Hopkins and Williams Ltd).

Growth medium. The cultures were grown in medium 199 (Morgan, Morton and Parker, 1950) supplemented with 5 per cent. calf serum, 0.88 per cent. sodium bicarbonate, 100 units penicillin per $\mathrm{ml}$ and $100 \mu \mathrm{g}$ streptomycin per $\mathrm{ml}$. The maintenance medium was medium

Received 18 June 1969; accepted 6 Oct. 1969.

* Present address: Department of Pathology, The Royal Veterinary College, Royal College Street, London, N.W.1. The author was on secondment from the Wellcome Foundation Limited. 
199 supplemented with 1 per cent. calf serum, 1.76 per cent. sodium bicarbonate, 100 units penicillin per $\mathrm{ml}$ and $100 \mu \mathrm{g}$ streptomycin per $\mathrm{ml}$.

Growth rate. The rate of growth of the cells in culture was determined by the method of Fogh and Lund (1957).

Cytogenetic studies. The cells were grown on coverslips and processed by the method of Rothfels and Simonovitch (1958).

Implantation of cells into hamster cheek pouch. This was performed by the method of Handler and Foley (1956).

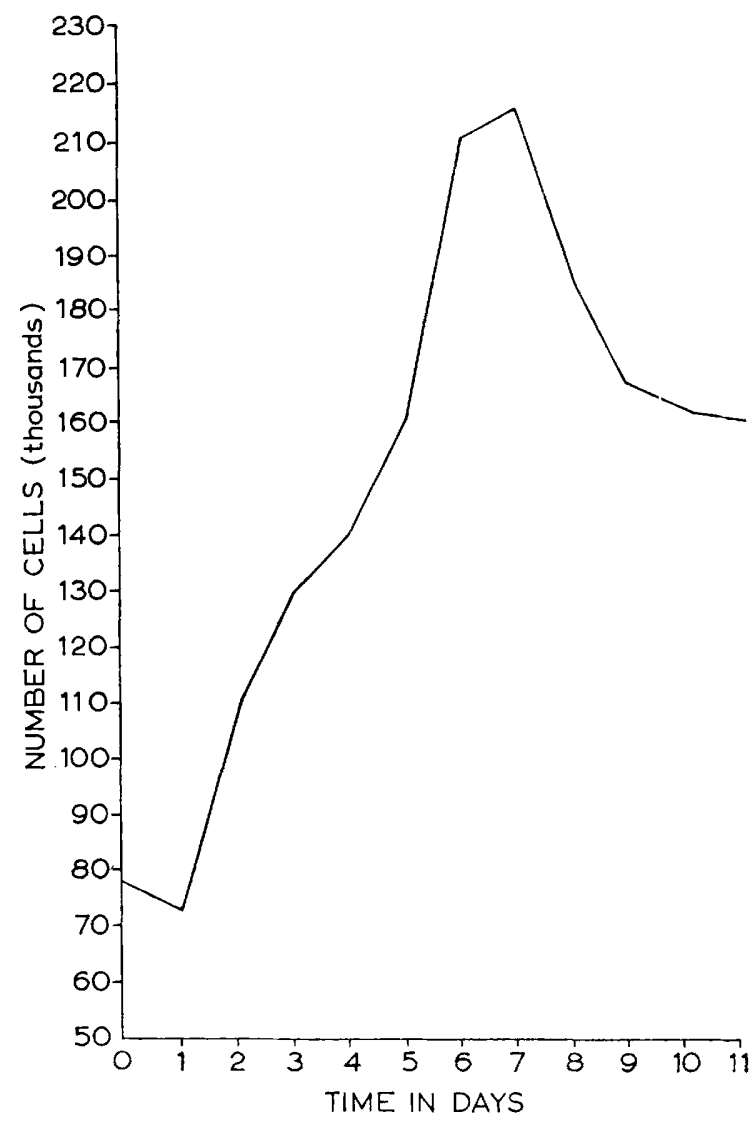

FIG. 1.-Growth of vervet monkey kidney cell line GL-V3 at the 65th passage in growth medium at $37^{\circ} \mathrm{C}$.

Viruses. Experiments to determine the comparative viral sensitivity of GL-V3 and secondary vervet monkey kidney cells were carried out with stock viruses. These viruses were provided by the Institute of Child Health at Great Ormond Street and by Glaxo Laboratories.

Titration of viruses. Serial ten-fold dilutions of the viruses were prepared in tissue culture medium 199, and 0.5-ml volumes of each dilution were inoculated into each of three testtube cultures of GL-V3 and secondary vervet monkey kidney cells. The inoculated cultures were incubated at $37^{\circ} \mathrm{C}$ in a roller-tube incubator and were examined microscopically on the 3rd, 5th, 7th, 9th and sometimes on the 12th and 14th day after inoculation for the presence of cytopathic changes. The number of tissue culture infective doses (TCID50) was calculated by the method of Reed and Muench (1938). 

eosin.

Control and virus-infected culture preparations were stained with haematoxylin and

\section{RESULTS}

Cell culture. Out of 12 attempts, two cell lines, termed GL-V3 and GL-V8, were established. Their development was similar. There was early vigorous growth for eight passages, during which the cells were trypsinised twice a week. From the 8 th to the 16th subculture the rate of growth slowed down and the cells were trypsinised every 10 days. At the 16 th passage the growth rate increased again and from then on the cells could be subcultured as cell lines. Cell line GL-V8 was stored at $-70^{\circ} \mathrm{C}$ and no further study of it was undertaken.

TABLE I

Chromosome numbers in $G L-V 3$ cells in different passages of culture after primary isolation from vervet monkey kidney

\begin{tabular}{|c|c|c|c|c|c|c|c|c|c|c|c|c|}
\hline \multirow{3}{*}{$\begin{array}{l}\text { Passage } \\
\text { no. }\end{array}$} & \multicolumn{12}{|c|}{ Number of metaphases counted in passaged culture in which } \\
\hline & \multicolumn{11}{|c|}{ the chromosome number was } & \multirow{2}{*}{$\begin{array}{l}\text { the nucleus was } \\
\text { hypotetraploid }\end{array}$} \\
\hline & 48 & 49 & 50 & 51 & 52 & 53 & 54 & 56 & 57 & 58 & 60 & \\
\hline $\begin{array}{l}15 \\
25 \\
40 \\
60 \\
75\end{array}$ & $\begin{array}{l}0 \\
0 \\
0 \\
4 \\
2\end{array}$ & $\begin{array}{l}0 \\
0 \\
0 \\
4 \\
2\end{array}$ & $\begin{array}{l}0 \\
0 \\
4 \\
4 \\
6\end{array}$ & $\begin{array}{l}0 \\
0 \\
4 \\
3 \\
3\end{array}$ & $\begin{array}{r}0 \\
0 \\
8 \\
24 \\
31\end{array}$ & $\begin{array}{l}0 \\
0 \\
5 \\
5 \\
7\end{array}$ & $\begin{array}{r}0 \\
11 \\
10 \\
12 \\
12\end{array}$ & $\begin{array}{l}0 \\
4 \\
1 \\
0 \\
0\end{array}$ & $\begin{array}{l}0 \\
1 \\
0 \\
0 \\
0\end{array}$ & $\begin{array}{l}1 \\
0 \\
0 \\
0 \\
0\end{array}$ & $\begin{array}{r}20 \\
6 \\
0 \\
0 \\
0\end{array}$ & $\begin{array}{l}0 \\
0 \\
0 \\
0 \\
2\end{array}$ \\
\hline
\end{tabular}

Growth rate of $G L-V 3$. Cells of GL-V3 at the 65 th passage were used to determine their rate of growth. The growth curve is illustrated in fig. 1. A lag phase lasting $24 \mathrm{hr}$ was observed, after which the cells entered a logarithmic phase lasting for 6 days. After the 7 th day the cell numbers began to decline. These experiments indicated that the generation time of the cells was approximately $90 \mathrm{hr}$.

Cytogenetic studies. Examination of chromosome preparations from secondary vervet monkey kidney cultures confirmed the report of Chu and Giles (1957) that the diploid chromosome number in the somatic cell of the African green vervet monkey is 60 . Cells derived from the 15th, 25th, 40th, 60th and 75 th passages were also examined to determine the number of chromosomes and it was found that GL-V3 cells were diploid up to the 15 th passage, but deviated to a hypodiploid chromosome complement from the 25 th passage onward. A few hypotetraploid cells appeared at the 75 th passage. The results are presented in table I.

\section{Isolation of viruses from clinical material}

GL-V3 cells of the 60th to the 80th passages were tested for primary isolation of a variety of viruses from specimens of throat secretion, nasal secretion 
and faeces known to contain the virus, and the results are given in table II. The results indicate that GL-V3 cells may be employed successfully in the isolation of poliovirus, Coxsackie viruses, Herpesvirus hominis, adenoviruses, echoviruses and an $M$ strain of rhinovirus.

\section{Susceptibility of GL-V3 cells to viruses compared with that of secondary vervet cells}

The susceptibility of the GL-V3 cell line to stock viruses was investigated and compared with that of secondary vervet monkey kidney cells. The results,

TABLE II

Isolation of viruses from specimens of throat secretion, nasal secretion and faeces in cultures of $G L-V 3$ cells

\begin{tabular}{c|l|c}
\hline $\begin{array}{c}\text { Serial no. } \\
\text { of specimen }\end{array}$ & $\begin{array}{c}\text { Type of virus known to } \\
\text { be present in specimen }\end{array}$ & $\begin{array}{c}\text { No. of days required to } \\
\text { isolate virus in GL-V3 } \\
\text { cells* }\end{array}$ \\
\hline 7 & $\begin{array}{l}\text { Rhinovirus M strain } \\
\text { Echovirus type 6 }\end{array}$ \\
10 & Poliovirus type 3 & 6 \\
14 & Poliovirus type 3 & 4 \\
15 & Echovirus type 9 & 4 \\
18 & Coxsackievirus type B2 & 7 \\
461 & Rhinovirus H strain & 4 \\
1906 & Coxsackievirus type A3 & 2 \\
1946 & Poliovirus type 2 & 4 \\
2094 & Coxsackievirus type A9 & 6 \\
2479 & Adenovirus type 1 & 3 \\
2761 & Herpesvirus hominis & 2 \\
\hline
\end{tabular}

* The appearance of a characteristic cytopathic effect on the day stated was the criterion on which the isolation of a virus was based. The viruses were identified and typed by serological methods.

presented in tables III and IV, indicate that GL-V3 cells are susceptible to a wide range of viruses. The titres of most viruses in confluent (5-7-days-old) GL-V3 cultures were similar to if not identical with those in secondary vervet monkey kidney cultures.

\section{Implantation of GL-V3 cells into hamster cheek pouches}

Suspensions of GL-V3 cells from 75th passage cultures were implanted into the cheek pouches of hamsters in $0 \cdot 1-\mathrm{ml}$ volumes. Half the number of hamsters had been conditioned by the administration of cortisone. The inocula used range from $10^{4}$ to $10^{6}$ cells per $0 \cdot 1 \mathrm{ml}$. The period of observation in this experiment was 45 days. For control purposes, implantations were also made with cell suspensions prepared from the HeLa cell line, which is known to be neoplastic.

Hamsters into which GL-V3 cells had been implanted remained normal, and no tumours were formed during the period of observation. Histological 
examination of the pouches of these hamsters confirmed that no abnormality was produced at the site of cell inoculation. One of four hamsters receiving $10^{5} \mathrm{HeLa}$ cells and each of four hamsters receiving $10^{6} \mathrm{HeLa}$ cells developed tumours.

TABLE III

Susceptibility of GL-V3 cells to various viruses compared with that of secondary vervet kidney cells

\begin{tabular}{|c|c|c|c|c|c|}
\hline \multirow{2}{*}{\multicolumn{2}{|c|}{ Virus }} & & & \multicolumn{2}{|c|}{$\begin{array}{l}\text { Titre of virus ( } \log _{10} \text { no. TCID50 per ml) } \\
\text { in fluid from culture in }\end{array}$} \\
\hline & & & & GL-V3 cells & $\begin{array}{l}\text { secondary } \\
\text { vervet cells }\end{array}$ \\
\hline $\begin{array}{l}\text { Sabin's polio, } \\
\text { type } 1 \\
\text { type } 2 \\
\text { type } 3 .\end{array}$ & $:$ & : & - & $\begin{array}{l}6 \cdot 3 \\
5 \cdot 3 \\
5 \cdot 8\end{array}$ & $\begin{array}{l}6 \cdot 3 \\
5 \cdot 8 \\
6 \cdot 8\end{array}$ \\
\hline $\begin{array}{c}\text { Coxsackie, } \\
\text { type A4 } \\
\text { type A7 } \\
\text { type B1 } \\
\text { type B2. }\end{array}$ & $\dot{.}$ & : & · & $\begin{array}{l}4 \cdot 3 \\
6 \cdot 8 \\
6 \cdot 8 \\
6 \cdot 3\end{array}$ & $\begin{array}{l}4 \cdot 3 \\
6 \cdot 8 \\
6 \cdot 8 \\
6 \cdot 8\end{array}$ \\
\hline $\begin{array}{c}\text { Influenza, } \\
\text { type A1 . } \\
\text { type B }\end{array}$ & . & ; & - & $\begin{array}{l}3 \cdot 8 \\
3 \cdot 3\end{array}$ & $\begin{array}{l}3 \cdot 8 \\
3 \cdot 3\end{array}$ \\
\hline $\begin{array}{l}\text { Parainfluenza, } \\
\text { type } 1 \\
\text { type } 2 \\
\text { type } 3\end{array}$ & : & . & & $\begin{array}{l}3 \cdot 3 \\
5 \cdot 8 \\
6 \cdot 8\end{array}$ & $\begin{array}{l}3 \cdot 3 \\
3 \cdot 8 \\
6 \cdot 3\end{array}$ \\
\hline Measles & . & . & . & $5 \cdot 8$ & $5 \cdot 3$ \\
\hline Rubella & . & . & . & $4 \cdot 8$ & (No CPE) \\
\hline Vaccinia & . & . & - & $8 \cdot 3$ & $8 \cdot 3$ \\
\hline Semliki forest & . & . & • & $7 \cdot 8$ & $7 \cdot 8$ \\
\hline Herpesvirus hom & ninis & . & & $6 \cdot 8$ & 6.8 \\
\hline
\end{tabular}

Test for latent viruses

Several experiments were made to detect the presence of latent viruses in GL-V3 cells. Test-tube cultures of GL-V3 cells were examined for haemadsorption and their fluids were tested for haemagglutination reactions. The results were negative. Amounts of $0.2 \mathrm{ml}$ of spent medium from GL-V3 cultures were inoculated into each of 20 test-tube cultures of secondary vervet monkey kidney cells and into each of 20 test-tube cultures of the human embryo lung cell strain, GL-HEL1. Replicate cultures were incubated at $37^{\circ}$ and $33^{\circ} \mathrm{C}$, and were examined microscopically every 2 nd day for 14 days. They remained free from cytopathic effect, and from haemadsorbing and haemagglutinating activity. 
Amounts of $0.2 \mathrm{ml}$ of spent medium from GL-V 3 cultures were inoculated into the allantoic cavity of six 9-day-old chick embryos and incubated at $37^{\circ} \mathrm{C}$ for 7 days. At the end of this period all chick embryos were healthy and alive. In addition, spent medium from GL-V3 cultures was inoculated in suckling mice, adult mice and rabbits. The animals were kept under observation for 20-60 days. During this period, the animals remained normal.

TABLE IV

Susceptibility of GL-V3 cells to simian viruses compared with that of secondary vervet kidney cells

\begin{tabular}{|c|c|c|c|c|c|c|}
\hline \multirow{2}{*}{\multicolumn{4}{|c|}{$\begin{array}{l}\text { Simian virus } \\
\text { group and number }\end{array}$}} & & \multicolumn{2}{|c|}{$\begin{array}{l}\text { Titre of virus ( } \log _{10} \text { no. TCID50 per ml) } \\
\text { in fluid from culture in }\end{array}$} \\
\hline & & & & & GL-V3 cells & $\begin{array}{l}\text { secondary } \\
\text { vervet cells }\end{array}$ \\
\hline $\begin{array}{l}\text { Group } 1 \text {, } \\
\text { no. } 1 \\
\text { no. } 17 \\
\text { no. } 32\end{array}$ & $\dot{.}$ & $\dot{.}$ & $\dot{r}$ & & $\begin{array}{l}6 \cdot 3 \\
6 \cdot 8 \\
4 \cdot 8\end{array}$ & $\begin{array}{l}6 \cdot 8 \\
6 \cdot 8 \\
4 \cdot 8\end{array}$ \\
\hline $\begin{array}{c}\text { Group } 2 \text {, } \\
\text { no. } 2 \\
\text { no. } 16 \\
\text { no. } 18\end{array}$ & . & $\dot{.}$ & $\dot{.}$ & & $\begin{array}{l}4 \cdot 8 \\
3 \cdot 8 \\
3 \cdot 3\end{array}$ & $\begin{array}{l}4 \cdot 8 \\
3 \cdot 8 \\
3 \cdot 3\end{array}$ \\
\hline $\begin{array}{c}\text { Group } 3 \text {, } \\
\text { no. } 4 \\
\text { no. } 12 \\
\text { no. } 28\end{array}$ & $\dot{.}$ & $\dot{r}$ & $\dot{r}$ & . & $\begin{array}{l}5 \cdot 8 \\
7 \cdot 3 \\
6 \cdot 3\end{array}$ & $\begin{array}{l}5 \cdot 3 \\
7 \cdot 3 \\
6 \cdot 8\end{array}$ \\
\hline $\begin{array}{c}\text { Group } 4 \text {, } \\
\text { no. } 5 \\
\text { no. } 26 \\
\text { no. } 40\end{array}$ & . & $\dot{5}$ & $\dot{.}$ & . & $\begin{array}{l}5 \cdot 3 \\
4 \cdot 8 \\
4 \cdot 8\end{array}$ & $\begin{array}{l}5 \cdot 8 \\
3 \cdot 8 \\
4 \cdot 8\end{array}$ \\
\hline
\end{tabular}

To find out whether the GL-V3 cell line was carrying any infective agent similar to that which caused acute illness and death among laboratory workers in Germany, $10^{6} \mathrm{GL}-\mathrm{V} 3$ cells were inoculated into each of six young guinea-pigs. Another six guinea-pigs were each given an inoculum of $1 \mathrm{ml}$ of spent medium. The animals were kept under observation for a period of $3 \mathrm{mth}$. During this period, the animals remained healthy. At necropsy no abnormalities were observed. The results of these experiments show that no latent viruses or other infective agents were isolated from cell line GL-V3.

\section{Discussion}

Since the vervet monkey kidney cell line designated GL-V3 has been cultivated in vitro for over $7 \mathrm{yr}$ and is still actively proliferating, the indications are that it has an indefinite expectancy of life. It is an epithelial cell and still shows a resemblance in its morphology to primary monkey kidney cultures. The 


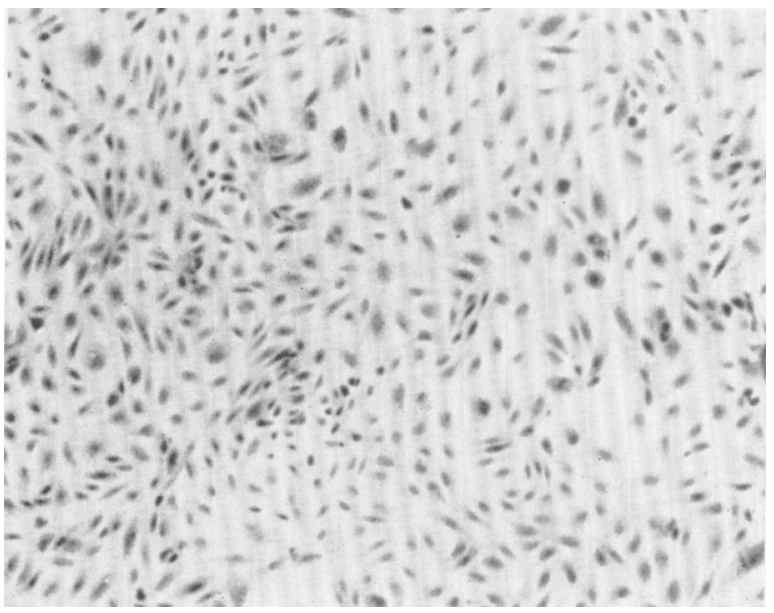

FIG. 2.-Uninfected (control) GL-V3 cell sheet after 70 passages. Haematoxylin and eosin (HE). $\times 65$.

FIG. 3.-GL-V3 cells of the 70th passage infected with simian virus 40 , showing cytopathic changes with polynucleated areas and vacuolation. HE. $\times 55$.
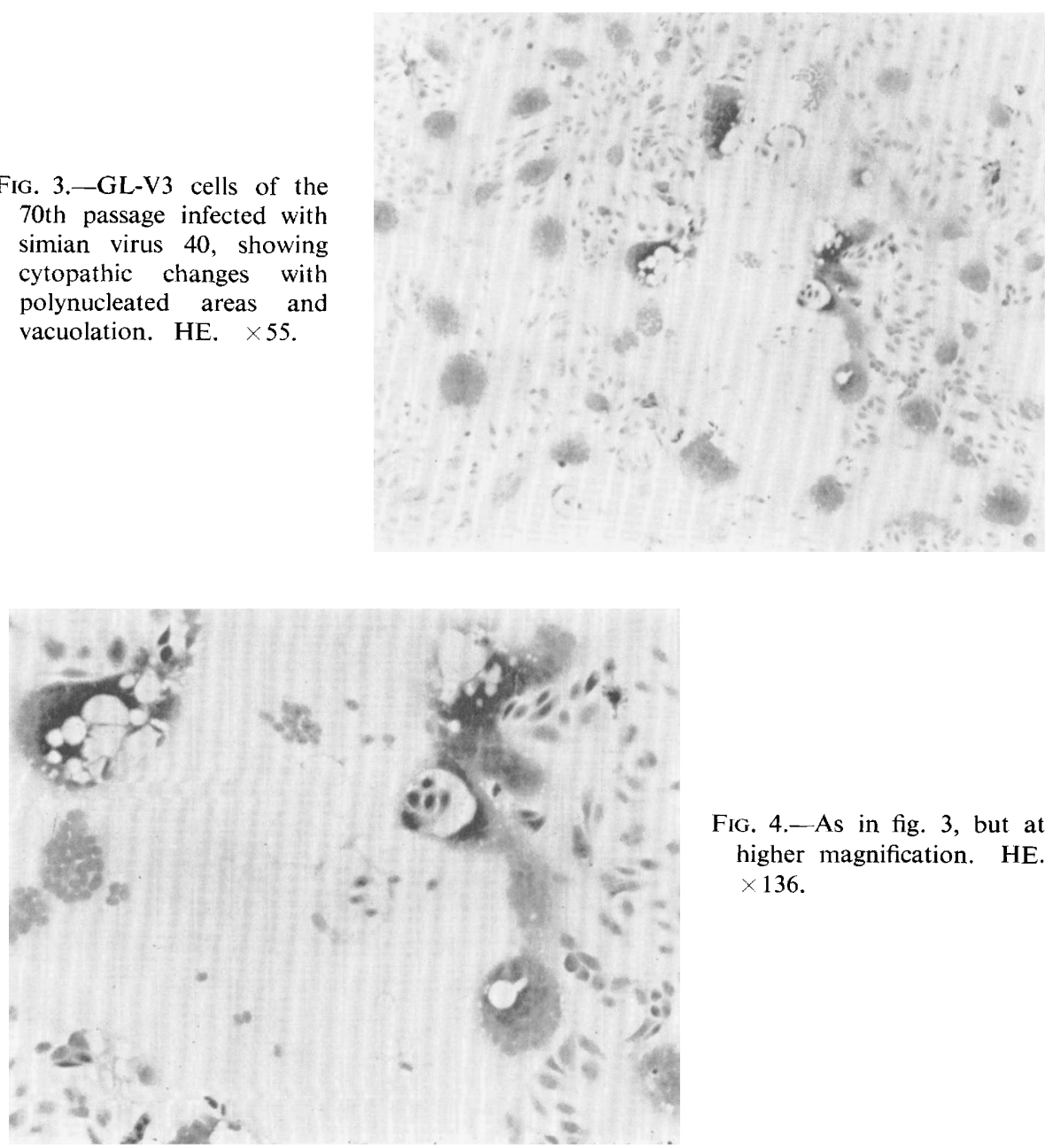

FIG. 4.-As in fig. 3, but at higher magnification. HE. $\times 136$. 
Cell line GL-V3

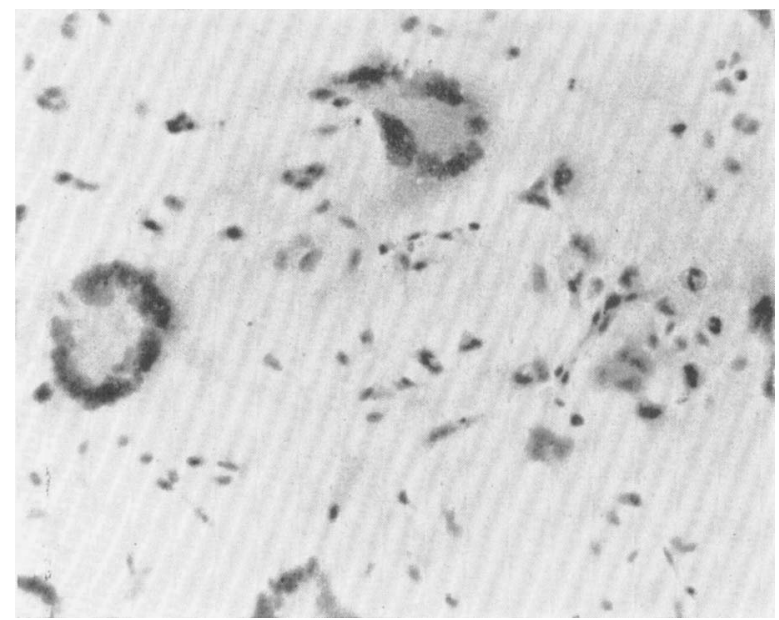

Fig. 5.-GL-V3 cells of the 75 th passage infected with measles virus, showing cytopathic changes with polynucleated areas. HE. $\times 95$.

FIG. 6.-As in fig. 5, but at higher magnification. HE. $\times 420$.

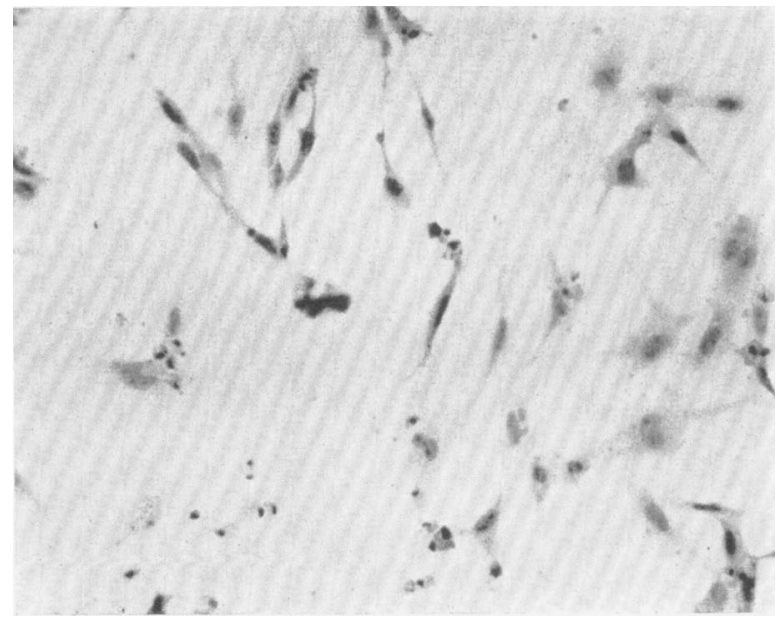

FIG. 7.-GL-V3 cells of the 72nd passage infected with rubella virus, showing cytopathic changes with nuclear and cytoplasmic pyknotic areas and the appearance of elongated cells. HE, $\times 95$. 
cytogenetic studies on GL-V3 revealed that the cells remained diploid up to the 15 th passage, but deviated to a hypodiploid complement of chromosomes from the 25 th passage onward. A progressive shift to lower chromosome numbers was observed. A few hypotetraploid cells appeared at the 75 th passage. Hopps et al. (1963) have reported similar observations.

The results show that GL-V3 can be usefully employed in the isolation, propagation and titration of simian viruses. The finding that the line is sensitive to SV5 and SV40 is significant in indicating the potential usefulness of the line for simian virus research. SV40 produced characteristic cytopathic changes with polynucleated areas and disruption of the monolayer with vacuolated areas (see figs. 2-4). Sensitivity to SV12 is of special interest as this virus is a strain of reovirus type 1 and GL-V3 cells are used in reovirus research. Cultures of GL-V3 cells also support the growth of several viruses including polio, measles, rubella, Coxsackie, herpes, vaccinia, influenza, parainfluenza and Semliki forest. Characteristic cytopathic changes with giant polynucleated areas produced by measles viruses are illustrated in figs. 5 and 6 . The cytopathic effect produced by rubella virus was characterised by nuclear and cytoplasmic pyknotic areas, an apparent disruption of the monolayer and the appearance of elongated type cells (fig. 7). In addition to its use in measles and reovirus research, the GL-V3 cell line is of special value for work with Coxsackie and parainfluenza viruses.

Since no latent viruses were detected in the GL-V3 cultures, and their cells were not neoplastic when tested by implantation in hamster cheek pouches, this cell line seems likely to be useful in virus diagnostic and research laboratories.

\section{SUMMARY}

A vervet monkey kidney cell line designated GL-V3 has been established. After 75 passages it still has the morphology of epithelial cells and its chromosome complement is aneuploid. Cultures of GL-V3 are susceptible to a wide range of viruses. No latent viruses were detected and the cells are not neoplastic when implanted in the cheek pouches of hamsters.

I wish to express my appreciation and thanks to Dr A. J. Beale and Professor A. O. Betts for helpful advice, and to thank Mr B. Melvin for staining the histological preparations and Mr D. Kedgley and Mrs B. Hall for the photographs.

\section{REFERENCES}

Bishop, L. W. J., Smith, M. K., AND 1960. Virology, 10, 280. Beale, A. J.

Chu, E. H. Y., ANd Giles, N. H. . 1957. Amer. Naturalist, 91, 273.

Fogh, J., And Lund, R. O. . . . . 1957. Proc. Soc. Exp. Biol. Med., 94, 532.

Gordon Smith, C. E., Simpson, D. I. H., 1967. Lancet, 2, 1119.

BOWEN, E. T. W., AND ZLOTNIK, I.

Handler, A. H., and Foley, G. E. . . 1 1956. Proc. Soc. Exp. Biol. Med., 91, 237.

Hopps, H. E., Bernheim, B. C., Nisalak, 1963. J. Immun., 91, 416.

A., TJio, J. H., AND SMadel, J. E.

Hull, R. N., AND MinNer, J. R. . . 1957. Ann. N.Y. Acad. Sci., 67, 413.

Hull, R. N., Minner, J. R., AND 1958. Amer. J. Hyg., 68, 31.

Mascoli, C. C. 
Hull, R. N., Minner, J. R., ANd Smith, 1956. Amer. J. Hyg., 63, 204. J. W.

Keeble, S. A., Christofinis, G. J., AND 1958. J. Path. Bact., 86, 189. WOOD, W.

Morgan, J. F., Morton, H. J., AND 1950. Proc. Soc. Exp. Biol. Med., 73, 1. PARKER, R. C.

Reed, L. J., AND Muench, H. . . . . 1938. Amer. J. Hyg., 27, 493.

Rothfels, K. H., AND Simonovitch, L. 1958. Stain Technol., 33, 73.

Rustiglan, R., Johnson, P., AND 1955. Proc. Soc. Exp. Biol. Med., 88, 8. REIHART, H.

Sweet, B. H., ANd Hilleman, M. R. $\quad$ - 1960. Ibid., 105, 420.

Wood, W., and Shimada, F. T. . . . 1954. Canad. J. Publ. Hlth, 45, 509. 